\title{
GEOGRAPHIC INFORMATION SYSTEM-BASED MODELING AND ANALYSIS FOR SITE SELECTION OF GREEN MUSSEL, Perna viridis, MARICULTURE IN LADA BAY, PANDEGLANG, BANTEN PROVINCE
}

\author{
I Nyoman Radiarta\#, Hatim Albasri, and Achmad Sudradjat \\ Center for Aquaculture Research and Development, Jakarta \\ (Received 14 March 2011 ; Accepted 6 May 2011 )
}

\begin{abstract}
Green mussel is one of important species cultured in Lada Bay, Pandeglang. To provide a necessary guidance regarding green mussel mariculture development, finding suitable site is an important step. This study was conducted to identify suitable site for green mussel mariculture development using geographic information system (GIS) based models. Seven important parameters were grouped into two submodels, namely environmental (water temperature, salinity, suspended solid, dissolve oxygen, and bathymetry) and infrastructural (distance to settlement and pond aquaculture). A constraint data was used to exclude the area from suitability maps that cannot be allowed to develop green mussel mariculture, including area of floating net fishing activity and area near electricity station. Analyses of factors and constraints indicated that about $31 \%$ of potential area with bottom depth less than $25 \mathrm{~m}$ had the most suitable area. This area was shown to have an ideal condition for green mussel mariculture in this study region. This study shows that GIS model is a powerful tool for site selection decision making. The tool can be a valuable tool in solving problems in local, regional, and/or continent areas.
\end{abstract}

KEYWORDS: green mussel, GIS, Site selection, Lada Bay

\section{INTRODUCTION}

Bivalves have been recognized as sources of animal protein with high nutritional value. Collected from wild habitats or aquaculture platforms, bivalve resources are widely exploited at subsistence level. Three major target species being cultured and harvested are oysters (Crassostrea sp.), cockles (Anadara sp.), and mussels (Perna sp.) (Vakily, 1989). The world aquaculture production of green mussel (Perna viridis) increased remarkably during the past 25 years, from less than 50,000 tons in 1980's to 300,000 tons in 2008 (FAO, 2011 ). In Indonesia, green mussel is one of important species being cultured because of its economical value and culture practicality. The culture method mainly uses off-bottom culture with ropes or wooden materials (stakes or bamboo poles) as a substrate for the mussel to settle and grow. Various modifications to the basic technique are added in order to increase the yield, adapt to the local condition, and make culture operation less labor intensive (Vakily, 1989).

Pandeglang District is one of potential aquaculture areas for green mussel in Banten Province. This aquaculture industry plays an important role on the economic and social

\# Corresponding author. Center for Aquaculture Research and Development, Jl. Ragunan 20, Pasar Minggu, Jakarta Selatan 12540, Indonesia. Tel.: +62 217805052

E-mail address: radiarta@yahoo.com 
welfare of the coastal communities in this district. Although, a planned aquaculture might have potential beneficial effects, but very often lack of adequate planning, or inappropriate site selection which in turn will increase the risk of environment problems. To ensure the legitimate uses of coastal space, environmental planning by means of optimum site selection is required. GESAMP (2001) emphasized that appropriate sitting of aquaculture development activities in coastal areas will contributed on minimizing the environmental impact, maximizing the overall economic return and minimizing conflict between aquaculture and other resource uses. Identification of sustainable aquaculture sites is a complex spatial problem and required depth knowledge of the marine and terrestrial environment as well as the understanding of several human factors (Valavanis, 2002). Site suitability may serve as the baseline information for variety of planning and management interventions (such as zoning or screening development proposals) to determine location and sitting of aquaculture activities. Those analyses can be built according to specific criteria such as environmental characteristics (physical, biological, and ecological factors), social and economical requirements, and infrastructure availability.

Geographic Information System (GIS) has been widely used in aquaculture development, including site selection and zoning, environmental impact assessment, inventory and monitoring of aquaculture and competition over coastal space (Kepetsky \& Anguilar-Manjarrez, 2007; Anguilar-Manjarrez et al., 2010). In terms of site selection and zoning, development of a complex model has been applied and demonstrated for scallops (Radiarta et al., 2008), mussels (Longdill et al., 2008) marine fish (Pérez et al., 2005), tilapia fish (Ross et al., 2010), giant prawn (Hossain \& Das, 2010), and kelp (Radiarta et al., 2011). FAO GISfish site (http://www.fao.org/fishery/gisfish/ index.jsp) provides more information on comprehensive case study related with the used of GIS and remote sensing either for aquaculture or capture fisheries. This paper presents a quantitative evaluation of coastal area using a range of available spatial data supplemented from field measurement and remote sensing, and modeled using GIS to identify suitable site for green mussel mariculture development in Lada Bay Pandeglang District Banten Province.

\section{MATERIALS AND METHODS}

This study was conducted in Lada Bay of Pandeglang District situated on the Southwestern part of Banten Province. It lies between $105^{\circ} 40^{\prime}-105^{\circ} 51^{\prime}$ East and 6०24-6³3' South (Figure 1). The climate of the study area is affected by two monsoon regimes, the northwest monsoon during November-May and southeast monsoon during June-October. During the annual cycle, the Southeast monsoon period is suitable for green mussel farming as calm sea water occurs due to low wind speed compared to the northwest monsoon. These monsoon regimes play an important role in the development of green mussel mariculture in the study area.

Infrastructure, constraints, and important basemap data were extracted from ALOS AVNIR2 satellite data with $10 \mathrm{~m}$ resolution, acquired on 2 July 2008 . This image was collected as level 1B2G (geo-coded). On-screen digitizing was the technique chosen to produce infrastructure, constraints as well as basemap features. Distance analysis (using ArcGIS spatial analyst) was used to convert into raster data and measure a distance for each infrastructure and constraints data.

The remote sensing and GIS software used in this study were ERDAS Imagine v.9.1 (ERDAS Atlanta, GA, USA) and ArcGIS v.9.3 (The Environmental System Research Institute, USA). Data processing and modeling were performed mainly with ArcGIS v.9.3, while ERDAS Image was used for image processing. All spatial data used in the GIS model were aligned to WGS 84 UTM zone 48 South coordinate system.

\section{Analytical Procedure}

The model structure for identifying suitable site for green mussel mariculture was based on hierarchical structure. The structure combines all criteria into several smaller groups (Malczewski, 2000). Figure 2 shows site selection analysis for green mussel culture in a hierarchical structure. This study identified 9 criteria, represented either as factors or constraints (Nath et al., 2000). A factor is a measure of the suitability of the criterion relative to the activity under consideration. A constraint is a restriction that serves to limit the alternative under consideration and is presented in Boolean format (containing either one or zero). These criteria were grouped into three submodels: environmental (water tem- 


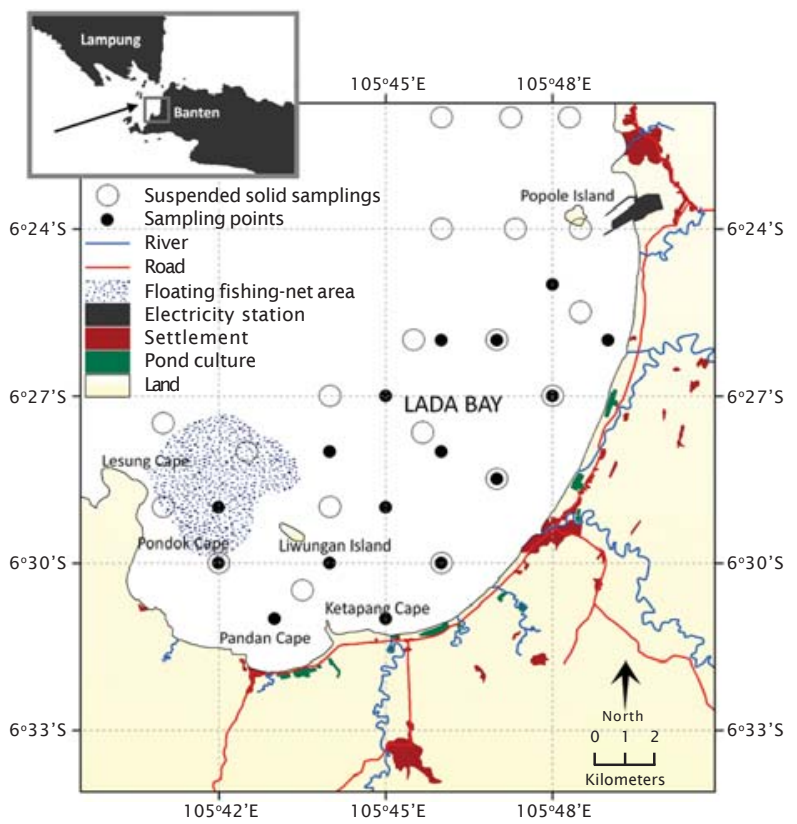

Figure 1. The study area in Lada Bay, Pandeglang, and distribution of sampling stations for water quality measurement. Suspended solid stations were extracted from Helfinalis (2005)

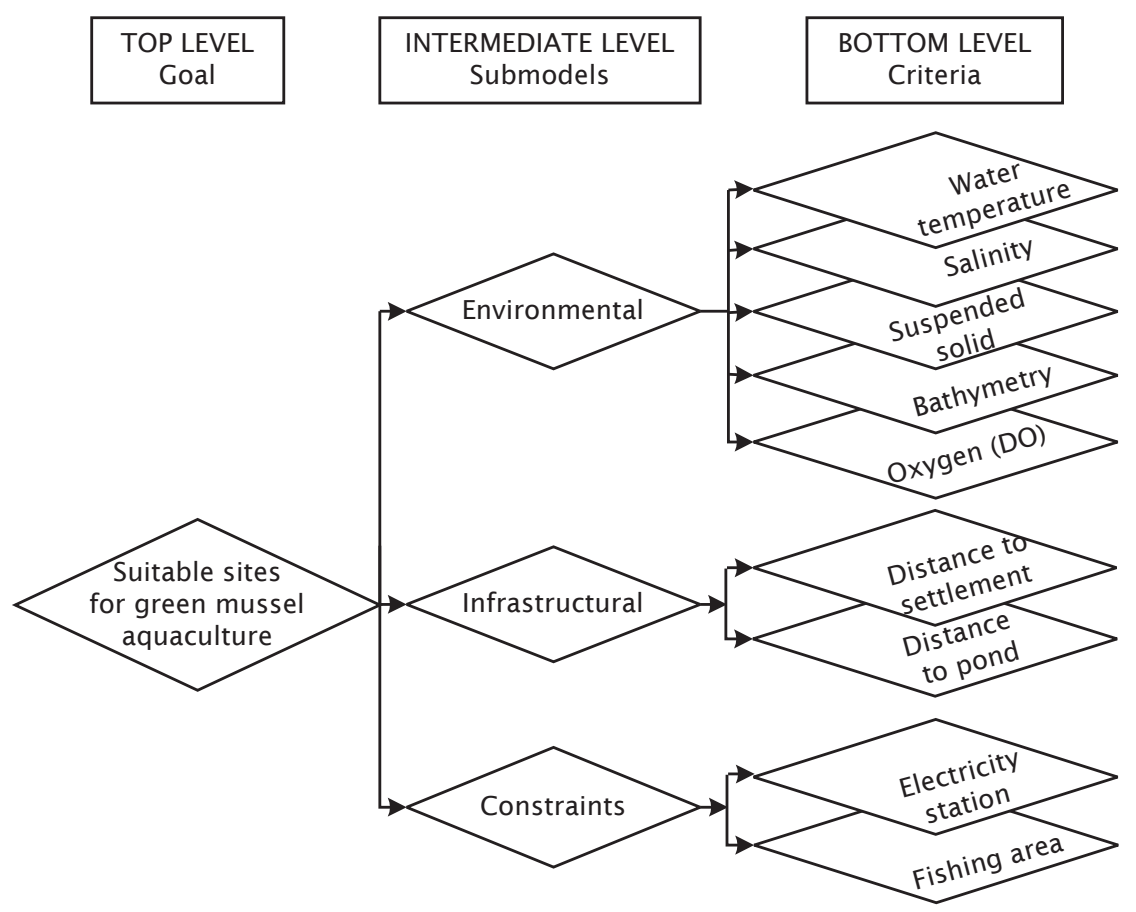

Figure 2. A hierarchical modeling scheme to identify suitable site for green mussel mariculture in Lada Bay, Pandeglang District Banten Province 
perature, salinity, suspended solid, dissolve oxygen, and bathymetry), infrastructural (distance to settlement and distance to pond aquaculture) and constraints (area near electricity station and floating fishing nets).

All data integrated into the spatial database needed some manipulation and reclassification to create a standard scoring method. Scoring of raw data was based on the level of importance of a particular factor that influences green mussel culture system. A set of suitability scores for each criterion was ranked and classified according to Giap et al. (2005) and Salam et al. (2005) using a scoring system from 1 to 4 , with 4 being the most suitable and 1 being not suitable for developing green mussel aquaculture (Table 1).

Parameter weights were determined by pairwise comparison in the context of decision making process known as the Analytical Hierarchy Process (Saaty, 1977). The preferences were typically defined as a value assigned to criterion that indicates its importance relative to other criteria under consideration. Their relative importance was obtained through literature review and experts' opinions (Table 2). The relative importance of the criteria was evaluated on a nine-point continuous scale from 1 (least important) to 9 (most important). The principal eigenvector of the pairwise comparison matrix was computed to produce the best fit for a total weight of 1 . In addition, consistency ratio was also calculated. This value indicates the level of acceptance of the judgment over compared criteria. A consistency ratio of 0.1 or less was considered acceptable (Saaty, 1977; Banai-Kashani, 1989).
Once the scores and weights of the spatial data had been determined, spatial modeling using GIS was applied. The modeling was constructed based on a multi-criteria evaluation procedure known as the weighted linear combination (Malczewski, 2000), using a formula as follows:

$$
V\left(x_{i}\right)=\sum_{j} w_{j} r_{i j}
$$

where $w_{j}$ is a normalized weight, such that $\Sigma w_{j}=1$, and $r_{i j}$ is the attribute transformed into the comparable scale. The weights represent the relative importance of the attributes. The most preferred alternative is selected by identifying the maximum value of $V(x)$ for $i=1$, $2, \ldots, m$.

\section{RESULTS}

In Lada Bay, stakes structures for green mussel culture are commonly placed in shallow water around 3-10 m depth. In order to minimize operation cost and difficulty in construction and maintenance of the structure, this model set $25 \mathrm{~m}$ as the maximum depth (potential area about $147 \mathrm{~km}^{2}$ ). The result for the seven criteria (as factors) and constraint layer is presented separately in two submodels namely environmental and infrastructural, enabling comprehensive analysis. The classifications of surface area for each criterion are summarized in Table 3, and the corresponding spatial distribution of suitability sites are shown in Figures 3 and 4.

Potential sites for green mussel culture should have appropriate environment variation in order to support the optimum condition for

Table 1. Environmental and infrastructural requirement and suitability scores for green mussel mariculture in Lada Bay Pandeglang District Banten Province

\begin{tabular}{lccccc}
\hline \multicolumn{1}{c}{ Parameters } & Unit & $\begin{array}{c}\text { Most } \\
\text { suitable }\end{array}$ & Suitable & $\begin{array}{c}\text { Moderately } \\
\text { suitable }\end{array}$ & $\begin{array}{c}\text { Not } \\
\text { suit able }\end{array}$ \\
\cline { 2 - 6 } & & $\mathbf{( 4 )}$ & $\mathbf{( 3 )}$ & $\mathbf{( 2 )}$ & $(\mathbf{1})$ \\
\hline Bathymetry & $\mathrm{m}$ & $3-10$ & $10-15$ & $15-20$ & $>20 ;<3$ \\
Salinity & $\mathrm{psu}$ & $30-32$ & $29-30 ; 32-34$ & $27-29 ; 34-35$ & $<27 ;>35$ \\
Dissolve oxygen & $\mathrm{mg} / \mathrm{L}$ & $>5$ & $3-5$ & $1-3$ & $<1$ \\
Sea temperature & ${ }^{\circ} \mathrm{C}$ & $25-30$ & $20-25 ; 30-33$ & $14-20 ; 33-35$ & $<14 ;>35$ \\
Suspended solid & & $<0.04$ & $0.04-0.05$ & $0.05-0.06$ & $>0.06$ \\
Distance to pond culture & $\mathrm{km}$ & $>2.0$ & $2.0-1.5$ & $1.5-1.0$ & $<1.0$ \\
Distance to settlement & $\mathrm{km}$ & $<4$ & $4-6$ & $6-8$ & $>8$ \\
\hline
\end{tabular}


Table 2. A pairwise comparison matrix for assessing relative importance of environmental and infrastructural criteria for green mussel aquaculture site selection in Lada Bay Pandeglang District (numbers show the rating of the row factors relative to the column factor)

\begin{tabular}{|c|c|c|c|c|c|c|}
\hline Environmental & Bathymetry & $\begin{array}{c}\text { Water } \\
\text { temperature }\end{array}$ & Salinity & $\begin{array}{l}\text { Suspended } \\
\text { solid }\end{array}$ & $\begin{array}{c}\text { Dissolve } \\
\text { oxygen }\end{array}$ & Weight \\
\hline Bathymetry & 1 & 1 & 2 & 3 & 4 & 0.33 \\
\hline Water temperature & 1 & 1 & 2 & 2 & 3 & 0.29 \\
\hline Salinity & $1 / 2$ & $1 / 2$ & 1 & 2 & 3 & 0.19 \\
\hline Suspended solid & $1 / 3$ & $1 / 2$ & $1 / 2$ & 1 & 2 & 0.12 \\
\hline Dissolve oxygen & $1 / 4$ & $1 / 3$ & $1 / 3$ & $1 / 2$ & 1 & 0.07 \\
\hline \multicolumn{7}{|l|}{ Consistency ratio (CR): 0.019} \\
\hline Infrastructural & $\begin{array}{l}\text { Distance to } \\
\text { settlement }\end{array}$ & \multicolumn{2}{|c|}{$\begin{array}{l}\text { Distance to } \\
\text { pond culture }\end{array}$} & & & Weight \\
\hline Distance to settlement & 1 & \multicolumn{2}{|l|}{$4 / 3$} & & & 0.57 \\
\hline Distance to pond culture & $3 / 4$ & \multirow{2}{*}{\multicolumn{2}{|c|}{1}} & & & 0.43 \\
\hline \multicolumn{5}{|l|}{ Consistencyratio (CR): 0.00} & & \\
\hline Overall model & Environmental & \multicolumn{2}{|c|}{ Infrastructural } & & & Weight \\
\hline Environmental & 1 & \multicolumn{2}{|l|}{$3 / 2$} & & & 0.6 \\
\hline Infrastructural & $2 / 3$ & \multirow{2}{*}{\multicolumn{2}{|c|}{1}} & & & 0.4 \\
\hline Consistencyratio (CR): 0.00 & & & & & & \\
\hline
\end{tabular}

Table 3. Areas (ha) and different suitability levels (\%) for green mussel aquaculture in Lada Bay Pandeglang, total study area for suitability analysis is $147 \mathrm{~km}^{2}$

\begin{tabular}{|c|c|c|c|c|c|c|c|c|c|c|}
\hline \multirow[t]{2}{*}{ Variables } & \multicolumn{2}{|c|}{$\begin{array}{c}\text { Const raint s } \\
\text { (0) }\end{array}$} & \multicolumn{2}{|c|}{$\begin{array}{c}\text { Not } \\
\text { suit able } \\
(1)\end{array}$} & \multicolumn{2}{|c|}{$\begin{array}{l}\text { Moderately } \\
\text { suit able } \\
\text { (2) }\end{array}$} & \multicolumn{2}{|c|}{$\begin{array}{c}\text { Suit able } \\
\text { (3) }\end{array}$} & \multicolumn{2}{|c|}{$\begin{array}{c}\text { Most } \\
\text { suit able } \\
(4)\end{array}$} \\
\hline & km & $\%$ & km & $\%$ & km & $\%$ & km & $\%$ & km & $\%$ \\
\hline Water te mperature & 23 & 16 & 0 & 0 & 0 & 0 & 101 & 69 & 23 & 15 \\
\hline Salinity & 23 & 16 & 0 & 0 & 0 & 0 & 88 & 60 & 36 & 24 \\
\hline Suspended solid & 23 & 16 & 0 & 0 & 0 & 0 & 45 & 30 & 79 & 54 \\
\hline Bathy metry & 23 & 16 & 16 & 11 & 15 & 10 & 22 & 15 & 71 & 48 \\
\hline Dissolve oxygen & 23 & 16 & 0 & 0 & 0 & 0 & 0 & 0 & 124 & 84 \\
\hline Environmental submodel & 23 & 16 & 0 & 0 & 2 & 1 & 77 & 52 & 45 & 31 \\
\hline Distance to settlement & 23 & 16 & 0 & 0 & 12 & 8 & 32 & 22 & 80 & 54 \\
\hline Distance to pond culture & 23 & 16 & 10 & 7 & 9 & 6 & 10 & 7 & 95 & 64 \\
\hline Infrastructural submodel & 23 & 16 & 0 & 0 & 0 & 0 & 64 & 43 & 60 & 41 \\
\hline $\begin{array}{l}\text { Overall suitable site model } \\
\text { for green mussel }\end{array}$ & 23 & 16 & 0 & 0 & 2 & 1 & 77 & 52 & 45 & 31 \\
\hline
\end{tabular}

growth and survival. Water temperature, oxygen, suspended solid, and bathymetry were the parameters used to examine the environmental capability of the site. Approximately one- third of the potential area (31\%) was identified as most suitable area, and these areas were mostly located around Liwungan Island in the southern part of the region (Figure $3 a$ ). The 

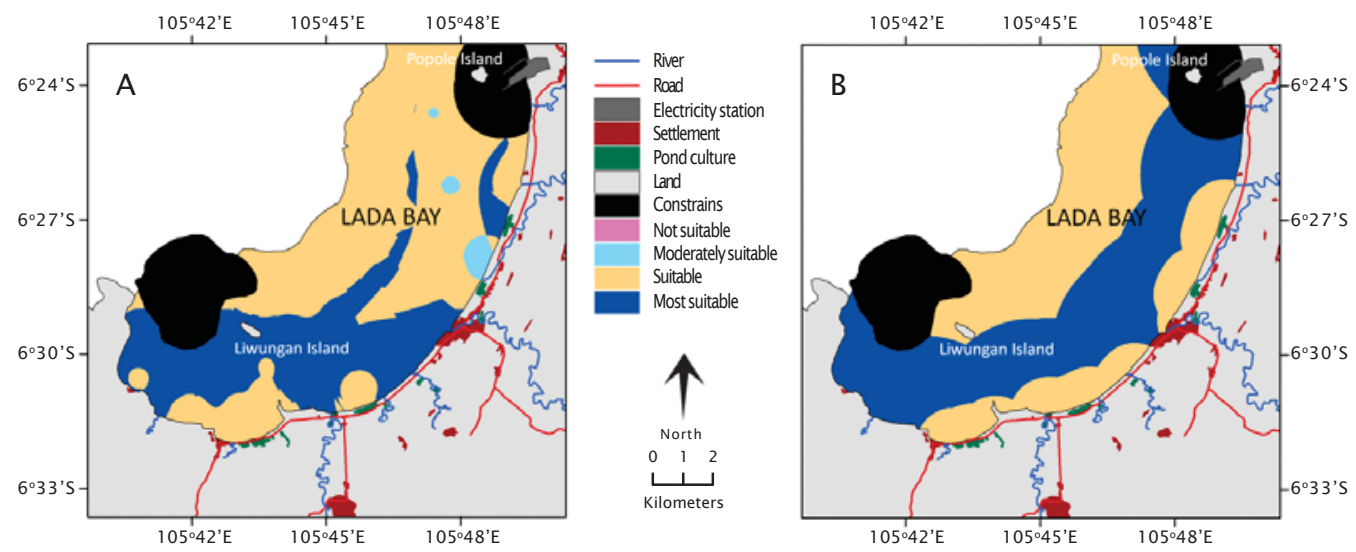

Figure 3. Suitability maps for different sub-models generated for green mussel mariculture in Lada Bay, Pandeglang: (a) environmental submodel and (b) infrastructural submodel

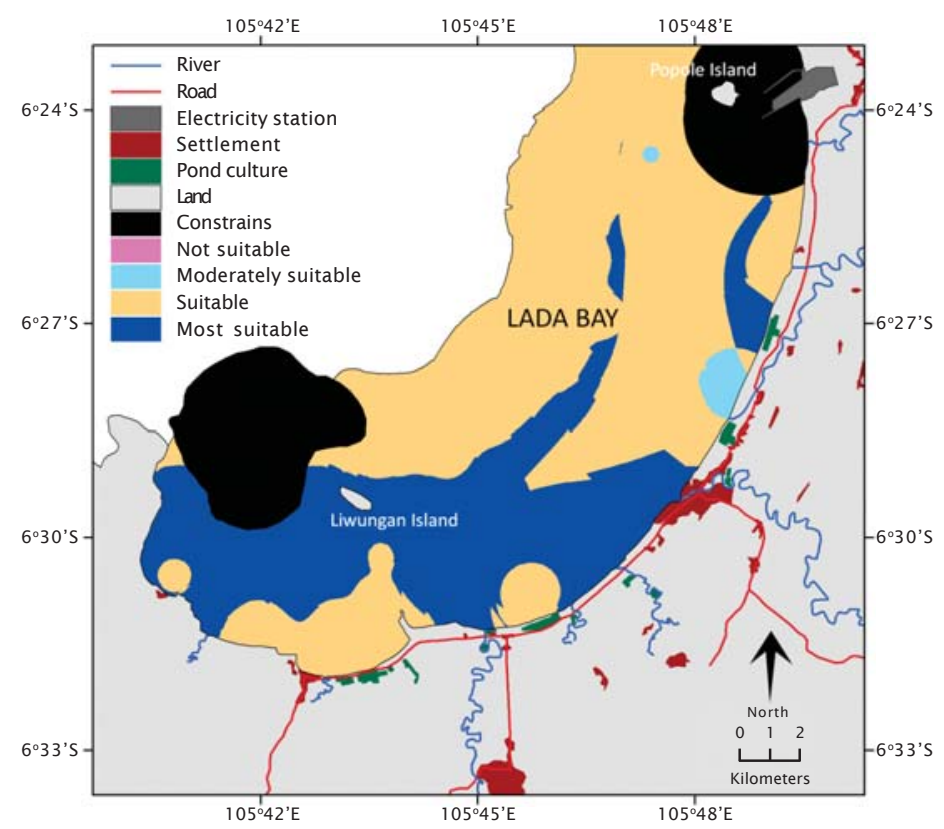

Figure 4. Final site selection map for green mussel aquaculture in Lada Bay, Pandeglang

study area contains no unsuitable area in term of environmental condition. About 15\%-54\% of potential area was classified as most suitable for green mussel culture in term of water temperature, salinity, bathymetry, and suspended solid (Table 3).

The improvement of productivity and product quality can be influenced by the condition of available infrastructures. Distances to settlement and pond culture were the parameter used to examine the influence of infrastructure on the green mussel development in the study region. Approximately $41 \%$ of potential areas were classified as most suitable for green mussel culture in term of infrastructural factor (Table 3). This area is distributed evenly around the bay (Figure $3 b$ ). About $43 \%$ were identified as suitable. There was no area classified as not suitable. 
The constraint area limits the suitable site for green mussel culture. Fishing activity using floating net located near the Liwungan Island and area near electricity station located near the Popole Island were considered as constraints (Figure 1). These areas covered about $16 \%\left(23 \mathrm{~km}^{2}\right)$ of the potential area in this study region (Table 3 ).

In the final output for green mussel culture site suitability (Figure 4), the model predicted that $45 \mathrm{~km}^{2}$ (31\%) of potential area was classified as the most suitable area. This area is distributed around the Liwungan Island on the southern part of the study region that has ideal conditions for the criteria examined. About half of the potential area (52\%) was classified as suitable site. Only $2 \mathrm{~km}^{2}$ (1\%) of potential area was identified as moderately suitable. However there was no area identified as not suitable site.

\section{DISCUSSION}

This study focused on the selection of suitable site for green mussel using stakes culture technique. Different criteria were grouped into two submodels, namely environmental and infrastructural which were combined to produce a final suitability map. Although, the total potential area in this region was $147 \mathrm{~km}^{2}$ (area with water depth less than $25 \mathrm{~m})$, only about $84 \%\left(124 \mathrm{~km}^{2}\right)$ could be used for green mussel culture, while the remaining $16 \%\left(23 \mathrm{~km}^{2}\right)$ was categorized as constraints area. In general, Lada Bay is favorable for green mussel aquaculture development. Classification of suitability sites estimated that $31 \%$ and $52 \%$ of the potential area were classified as the most suitable and suitable respectively, for the green mussel culture development. The most suitable areas were located around Liwungan Island in the southern part of the study region (Figure 4). The most suitable areas for green mussel culture were those where most of parameters coincided with each other and have a high potential for mussel production.

Site selection analysis from this study could be improved through adding more specific data that have significant influence on green mussel growth and survival. Those data is highly important in estimating site capability in order to sustain the production, such as chlorophyll concentration (food availability), water current, wave height, seed availability, and pollution (Nath et al., 2000; Radiarta et al.,
2008). In addition, other socio-economic and infrastructure factors would also need to be considered and improved (Kingzet et al., 2002).

This study demonstrated the use of GIS to model site selection for green mussel culture in Lada Bay based on certain important criteria. An advantage of a GIS is the ability to upgrade, integrate and analyze when new information become available, which could change the existing scores. The model can be easily expanded or updated to generate a new model (map). On the other hand, the quality and quantity of available information (up to date and high quality) will lead an analyst to make a more precise estimation and better decision making (Nath et al., 2000). In aquaculture development, GIS play an important role to facilitate the decision maker in the process of management and sustainable use of natural resources (AnguilarManjarrez et al., 2010). The development of advance technology and the better uses of available technology such as GIS and RS can further enhance the development of generic frameworks/models that can be used by coastal planners and policy makers to integrate aquaculture-based activities in a sustainable manner.

\section{CONCLUSION}

In general, environmental and infrastructural conditions in the study area are favorable for green mussel mariculture. As expected, most areas in the bay had high suitability levels. The results of this study could give the general overview for future aquaculture zone planning in order to support environmentally sound aquaculture development and also carrying capacity assessment. The GIS model used in this study is a powerful tool for site selection decision making. This tool can be a valuable tool in solving problems in local, regional, and/or continent areas.

\section{ACKNOWLEDGMENT}

The authors acknowledge the Fisheries Agency of Banten Province and Pandeglang District for their valuable assistance during the field work. The authors would like to thank to other research members of Minapolitan Research Program of the Center for Aquaculture Research and Development (CARD) for fruitful discussion and assistance. This study was part of CARD Minapolitan Research Program, and supported by CARD Financial Budget (DIPA) of the fiscal year of 2010. 


\section{REFERENCES}

Anguilar-Manjarrez, J., Kapetsky, J., \& Soto, D. 2010. The potential of spatial planning tools to support the ecosystem approach to aquaculture. FAO/Rome. Expert Workshop. 19-21 November 2008, Rome, Italy. FAO Fisheries and Aquaculture Proceedings. No. 17. Rome, FAO. 2010, 176 pp.

Banai-Kashani, R. 1989. A new method for site suitability analysis: the analytic hierarchy process. Environmental Management, 13: 685-693.

FAO. 2011 . Species Fact Sheets Perna viridis (Linnaeus, 1758). Available online at: http:/ /www.fao.org/fishery/species/2691/en. Cited 8 March 2011.

GESAMP (IMO/FAO/Unesco-IOC/WMO/WHO/ IAEA/UN/UNEP Joint Group of Experts on the Scientific Aspects of Marine Environmental Protection), 2001. Planning and management for sustainable coastal aquaculture development. FAO Rep. Stud. GESAMP No. 68, 90 pp.

Giap, D.H., Yi, Y., \& Yakupitiyage, A. 2005. GIS for land evaluation for shrimp farming in Haipong of Vietnam. Ocean \& Coastal Management, 48: 51-63.

Helfinalis. 2005. Kandungan total suspended solid dan sedimen di dasar perairan Panimbang. Makara, Sains, 9 (2): 45-51.

Hossain, M.S., \& Das, N.G. 2010. GIS=based multi-criteria evaluation to land suitability modeling fro giant prawn (Marcobrachium rosenbergii) farming in Companigonj Upazila of Noakhali, Bangladesh. Computers and Electronic in Agriculture, 70: 172 186.

Johnson, K. \& J. McChow. 2001. Using ArcGIS spatial analysis. Environmental Systems Research Institute (ESRI), Inc, USA, 236 pp.

Kapetsky, J.M. \& Anguilar-Manjarrez, J. 2007. Geographic information systems, remote sensing and mapping for the development and management of marine aquaculture. FAO Fish. Tech. Pap. No. 458. Rome, 125 $\mathrm{pp}$.

Kingzet, B., Salmon, R., \& Canessa, R. 2002. First nations shellfish aquaculture regional business strategy. BC central and northern coast. Aboriginal relations and economic measures, Land and Water British Columbia Inc., $256 \mathrm{pp}$.

Malczewski, J. 2000. On the use of weighted linear combination method in GIS: common and best practice approach. Transaction in GIS, 4: 5-22.

Morain, S. 1999. GIS solution in natural resources management: balancing the technical-political equation. On world press. USA, 361 pp.

Nath, S.S., Bolte, J.P., Ross, L.G., \& AguilarManjarrez, J. 2000. Applications of geographical information systems (GIS) for spatial decision support in aquaculture. Aquacultural Engineering, 23: 233-278.

Longdill, P.C., Healy, T.R., \& Black, K.P. 2008. An integrated GIS approach for sustainable aquaculture management area site selection. Ocean \& Coastal Management, 51 : 612-624.

Pérez, O.M., Telfer, T.C., \& Ross, L.G. 2005. Geographical information system-based models for offshore floating marine fish cage aquaculture site selection in Tenerife, Canary Islands. Aquaculture Research, 36: 946-961.

Radiarta, I N., Saitoh, S-I., \& Miyazono, A. 2008. GIS-based multi-criteria evaluation models for identifying suitable sites for Japanese scallop (Mizuhopecten yessoensis) aquaculture in Funka Bay, Southwestern Hokkaido, Japan. Aquaculture, 284: 127135.

Radiarta, I N., Saitoh, S-I., \& Yasui, H. 2011. Aquaculture site selection for Japanese kelp (Laminaria japonica) in southern Hokkaido, Japan, using satellite remote sensing and GIS models. ICES J. of Marine Sciences, 68: 773-780.

Ross, L.G., Falconer, L.L., Mendoza, A.C., \& Palacios, C.A.M. 2010. Spatial modeling for freshwater cage location in the Presa Adolfo Mateos Lopez (El Infiernillo), Michoacan, Mexico. Aquaculture Research, doi:10.1111/j.1365-2109.2010.02689.x

Saaty, T.L. 1977. A Scaling Method for Priorities in Hierarchical Structures. J. of Mathematical Psychology, 15: 234-281.

Salam, M.A., Khatun, N.A., \& Ali, M.M. 2005. Carp farming potential in Barthatta Upazilla, Bangladesh: a GIS methodological perspective. Aquaculture, 245: 75-87.

Vakily, J.M. 1989. The biology and culture of mussels of the genus Perna. ICLARM Studies and Review 17,63 pp.

Valavanis, V. 2002. Geographic information systems in oceanography and fisheries. London: Taylor and Francis, 209 pp. 